\title{
Endocrine-disrupting activity of mancozeb
}

\section{Anatoly Skalny 1,2,3, Michael Aschner ${ }^{1,4}$, Monica Paoliello ${ }^{4}$, Abel Santamaria ${ }^{5}$, Natalia Nikitina ${ }^{1}$, Vladimir Rejniuk ${ }^{6}$, Yueming Jiang ${ }^{7}$, João Rocha ${ }^{8}$, Alexey Tinkov ${ }^{2,3,9}$}

\author{
${ }^{1}$ IM Sechenov First Moscow State Medical University, Moscow 119146, Russia \\ ${ }^{2}$ Peoples' Friendship University of Russia (RUDN University), Moscow 117198, Russia \\ ${ }^{3}$ Institute of Bioelementology, Orenburg State University, Orenburg 460018, Russia \\ ${ }^{4}$ Department of Molecular Pharmacology, Albert Einstein College of Medicine, Bronx, \\ NY 10461, USA \\ ${ }^{5}$ Laboratorio de Aminoácidos Excitadores/Laboratorio de Neurofarmacología Molecular y \\ Nanotecnología, Instituto Nacional de Neurología y Neurocirugía, Mexico City 14269, Mexico \\ ${ }^{6}$ Golikov Research Center of Toxicology, Saint Petersburg 192019, Russia \\ ${ }^{7}$ Department of Toxicology, School of Public Health, Guangxi Medical University, \\ Nanning 530021, China \\ ${ }^{8}$ Departamento de Bioquímica e Biologia Molecular, CCNE, Universidade Federal de Santa \\ Maria, Santa Maria, RS, Brazil \\ ${ }^{9}$ Yaroslavl State University, Yaroslavl 150000, Russia
}

* Corresponding author: Alexey Tinkov, e-mail: tinkov.a.a@gmail.com

\begin{abstract}
The objective of the present study was to review the existing data on the mechanisms involved in the endocrine disrupting activity of mancozeb (MCZ) in its main targets, including thyroid and gonads, as well as other endocrine tissues that may be potentially affected by MCZ. MCZ exposure was shown to interfere with thyroid functioning through impairment of thyroid hormone synthesis due to inhibition of sodium-iodine symporter (NIS) and thyroid peroxidase (TPO) activity, as well as thyroglobulin expression. Direct thyrotoxic effect may also contribute to thyroid pathology upon MCZ exposure. Gonadal effects of MCZ involve inhibition of sex

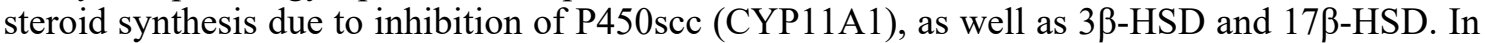
parallel with altered hormone synthesis, MCZ was shown to down-regulate androgen and estrogen receptor signaling. Taken together, these gonad-specific effects result in development of both male and female reproductive dysfunction. In parallel with clearly estimated targets for MCZ endocrine disturbing activity, namely thyroid and gonads, other endocrine tissues may be also involved. Specifically, the fungicide was shown to affect cortisol synthesis that may be mediated by modulation of CYP11B1 activity. Moreover, MCZ exposure was shown to interfere with PPAR $\gamma$ signaling, being a key regulator of adipogenesis. The existing data also propose that endocrine-disrupting effects of MCZ exposure may be mediated by modulation of hypothalamuspituitary-target axis. It is proposed that $\mathrm{MCZ}$ neurotoxicity may at least partially affect central mechanisms of endocrine system functioning. However, further studies are required to unravel the mechanisms of MCZ endocrine disrupting activity and overall toxicity.
\end{abstract}

Keywords: mancozeb, thyroid, testes, ovary, adrenal, adipose tissue doi.org/10.5937/arhfarm71-34359 


\section{Introduction}

Mancozeb (MCZ) is a dithiocarbamate fungicide widely used since 1962 for crop protection against a wide spectrum of fungal pathogens (1). Close relatives of MCZ from the same group of fungicides include Maneb and Zineb containing $\mathrm{Mn}^{2+}$ and $\mathrm{Zn}^{2+}$ ions, respectively (Figure 1).

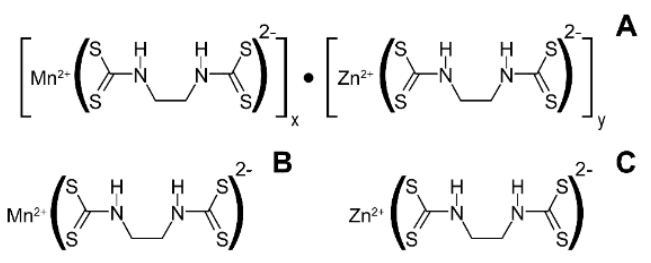

Figure 1. Structure of Mancozeb (A) and closely related dithiocarbamate fungicides, Maneb (B) and Zineb (C).

Slika 1. Struktura mankozeba (A) i srodnih ditiokarbamatskih fungicida, maneba (B) i cineba (C).

Environmental persistence of MCZ in soils was considered rather low (2), with halflife from 2 to 8 days in aerobic and anaerobic soils, respectively (3). However, MCZaffected soils were characterized by an increase in the formation of ethylthiourea (ETU), the main MCZ metabolite, for 30 days with a subsequent decline (4). Therefore, hazardous effects of MCZ exposure are expected to be observed at frequent use. At the same time, application of MCZ was shown to result in 20-fold increase in soil toxicity, with toxicity observed within more than $0.5 \mathrm{~km}$ from the application site (5). Although MCZ does not accumulate in plants, certain foods were shown to contain pesticide residues, thus posing significant health risks (6).

Although health hazards of mancozeb exposure are considered low in the case of safe occupational hygiene procedures (7), its wide use poses significant health hazards (8), especially in agricultural communities in developing countries (9).

It is considered that MCZ toxicity is widely attributed to toxic effects of its metabolite, ethylthiourea (Figure 2). Correspondingly, urinary ETU levels were found to correlate significantly with spraying mancozeb (10). However, certain studies demonstrate that adverse effects of MCZ exposure may be ETU-independent (11).

In human and experimental studies, $\mathrm{MCZ}$ was reported to have adverse effects on the immune system (12), gastrointestinal tract $(13,14)$, cardiovascular system (15), as well as carcinogenic effects (16). An increasing body of data has demonstrated profound reproductive, developmental, and thyroid-related toxicity of MCZ (17-19). Moreover, it has been shown that the thyroid and gonadal endocrine-disrupting effects upon MCZ exposure manifest without overt hepatotoxicity, indicative of endocrine system as a primary target for MCZ adverse effects (20). 


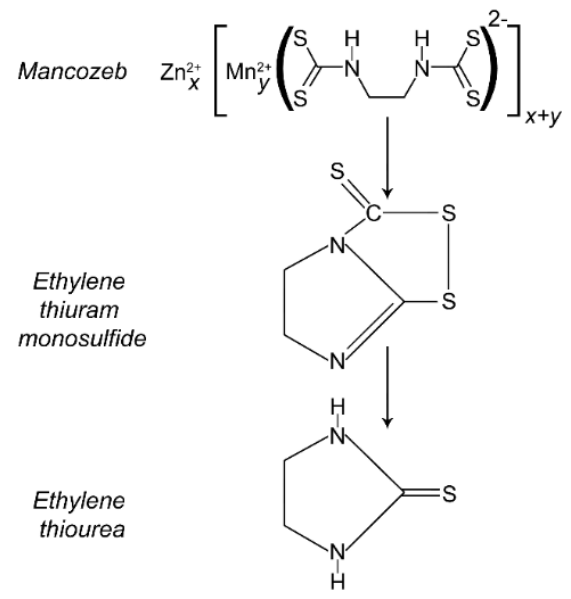

Figure 2. Formation of ethylenethiourea, a toxic metabolite of dithiocarbamate fungicides.

Slika 2. Nastajanje etilen tioureje, toksičnog metabolita ditiokarbamatskih fungicida.

Concomitantly, the mechanisms of MCZ toxicity in general, and its adverse effects on the endocrine system in particular, have yet to be fully characterized. Therefore, the objective of the present study was to review the existing data on the mechanisms involved in the endocrine disrupting activity of $\mathrm{MCZ}$ in its main targets, including the thyroid and gonads, as well as other endocrine tissues that may be potentially affected.

\section{Thyroid}

MCZ was shown to accumulate to a significant extent in the thyroid following exposure (16), thus predisposing to a wide spectrum of thyroid-associated pathologies. Particularly, lifetime exposure to $\mathrm{MCZ}$ was found to be positively associated with circulating higher T3 levels (17), although another study revealed an association between exposure rates and both hypo- and hyperthyroidism (18). However, no significant association between $\mathrm{MCZ}$ exposure and thyroid cancer was observed in farmers using fungicide (19). Examination of MCZ-exposed workers revealed significant increase in iodine excretion in association with exposure rates, indicative of thyroid-disrupting effects of MCZ and its metabolite ethylenthiourea (19).

Experimental studies have also shown a significant effect of MCZ on thyroid functioning, as evidenced by reduced T3 and T4 levels, although increased TSH concentrations in response to low T4 levels may be indicative of an adequate negative feedback mechanism. Reductions in thyroid hormone production were also associated with thyroid gland morphology, characterized by epithelial damage, altered stroma, and impaired follicle shape in birds (25). In pregnant rat dams, MCZ exposure also resulted in a dose-dependent decrease in T4 levels, although offspring T4 levels and thyroid 
weight were unaffected (26). However, in another study, maternal MCZ exposure resulted in morphological alterations in the thyroid, characterized by a high number of columnar vacuolated cells, indicative of higher secretory activity of the gland in rats (27). Taken together, these findings are indicative of altered thyroid hormone secretion upon $\mathrm{MCZ}$ exposure.

The underlying mechanisms of impaired thyroid functioning may involve the interference of $\mathrm{MCZ}$ with thyroid hormone synthesis, including inhibition of thyroid peroxidase (TPO) activity in vivo (28), which was also supported by molecular docking analysis (29). The inhibition of TPO would be expected to result in altered oxidation rate of iodine and its organification. In addition, MCZ was shown to compete with T3 for binding thyroid hormone receptor (30). Sodium-iodide transporter (NIS) may be also considered as the potential target for MCZ (31), thus reducing iodine availability for thyrocytes and thyroid hormone synthesis.

Other studies demonstrate that the MCZ metabolite ETU is responsible for its thyroid-disrupting activity. Specifically, comparative analysis demonstrated that both mancozeb and especially ETU were considered as thyroid disruptors, reducing intrafollicular T4-content in zebrafish eleutheroembryos by $50 \%$ and nearly to zero values, respectively (32).

ETU is known to be a potent TPO inhibitor with IC50 of $0.791 \mu \mathrm{M}$ (33), thus affecting a key step in thyroid hormone biosynthesis. Despite indications on the potential impact of ETU on NIS activity (34), a recent study failed to corroborate a selective inhibition of the transporter by ETU (31).

ETU-induced thyroid hormone imbalance may be also mediated by its direct thyrotoxic effects. In particular, in vitro transcriptomic analysis and in vivo study in ETUexposed mice demonstrated significant thyrotoxicity of ETU that was associated with a significant reduction in thyroid thyroglobulin and Bcl2 mRNA expression levels, altogether resulting in a decrease in free T4 levels (35). 


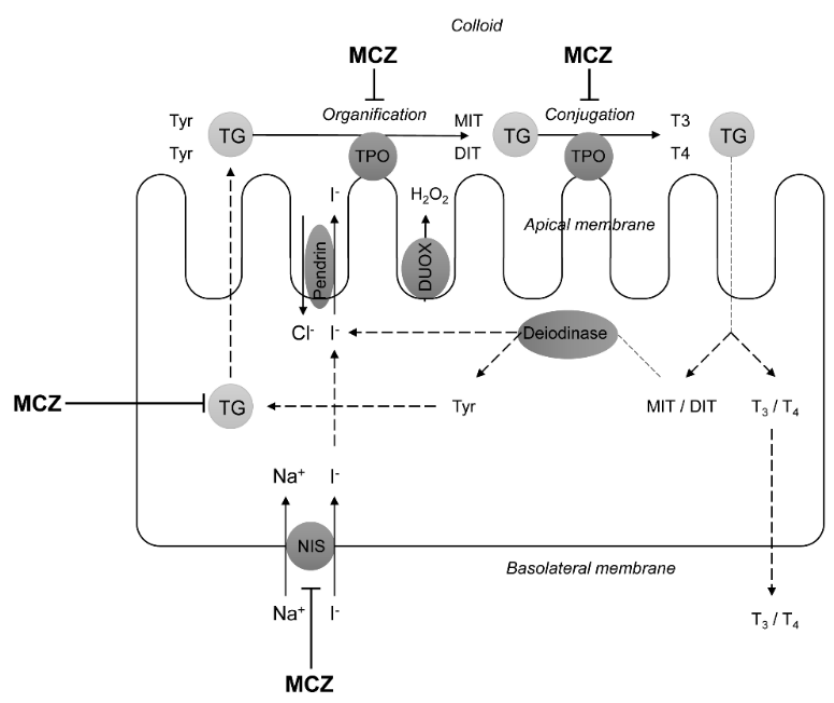

Figure 3. The potential mechanisms linking mancozeb exposure and thyroid disorders. MCZ - mancozeb, DUOX - dual oxidase, TPO - thyroid peroxidase, TG - thyroglobulin, NIS - sodium iodide symporter, MIT - monoiodothyronine, DIT - diiodothyronine, T3 - triiodothyronine, T4 - thyroxine.

Slika 3. Potencijalni mehanizmi koji povezuju izloženost mankozebu i tiroidne poremećaje. MCZ - mankozeb, DUOX - dual oksidaza, TPO - tiroidna perioksidaza, TG - tiroglobulin, NIS - natrijum-jodid simporter, MIT - monojodotironin, DIT - dijodotironin, T3 - trijiodotironin, T4 - tiroksin.

Despite its thyroid-targeted effects, the most recent analysis failed to show a significant relationship between ETU exposure rates and thyroid cancer, contrary to the reported carcinogenic effect of MCZ (36). However, in banana plantation workers, blood ETU levels were found to be significantly associated with thyroid nodule size (37).

\section{Testes}

Experimental studies demonstrated a significant association between mancozeb exposure and reduced testosterone levels, due to toxic impact on testes and especially testosterone-producing Leydig cells, as well as mechanisms of testosterone biosynthesis. Specifically, oral exposure to MCZ also resulted in a significant alteration of testicular morphology, with Sertoli cells (38) and Leydig cells (39) degeneration in rodents being the most prevalent. Moreover, a significant reduction in testes size, seminiferous tubule diameter, and germ cell and Sertoli cell number was observed in mice exposed to MCZ in utero and during lactation (40), indicative of prenatal endocrine-disrupting effect of $\mathrm{MCZ}$ on the male reproductive system.

MCZ exposure in male mice resulted in a significant decrease in basal plasma testosterone levels. Leydig cells isolated from these animals were also characterized by 
reduced basal testosterone and pregnenolone secretion, which may occur secondary to down-regulation of CYP11A1 activity (41). In addition, inhibition of testicular $3 \beta$ hydroxysteroid dehydrogenase and $17 \beta$-hydroxysteroid dehydrogenase is considered to be the potential mechanism for MCZ $(500 \mathrm{mg} / \mathrm{kg} \mathrm{b} . \mathrm{w})$-induced testosterone reduction (42). However, another study demonstrated an increase in testicular $3 \beta$-HSD activity in response to $100 \mathrm{mg} / \mathrm{kg}$ b.w MCZ exposure (43). Such an inconsistency may arise from distinct effects of various doses of $\mathrm{MCZ}$, which should be addressed in future doseresponse studies. Moreover, MCZ-induced alteration 3 $\beta$-HSD activity was accompanied by the disruption of testicular germinal epithelium, reduction of spermatogenic cells, and vacuolization of Leydig cells, as well as a significant decrease in serum FSH, LH, and testosterone concentrations in rabbits. Supplementation with GSH was shown to reverse these changes, implicating a role of oxidative stress in testicular MCZ-induced toxicity (43). In turn, apoptotic cell death was shown to follow MCZ-induced oxidative stress in testes (44).

In addition to reduced testosterone concentrations and impaired spermatogenesis, MCZ exposure also significantly decreased circulating estradiol and progesterone levels (15).

In parallel with reduced testosterone synthesis, MCZ was shown to affect its signaling through a down-regulating effect on the androgen receptor, as well as a dosedependent inhibitory effect on agonist-induced AR transactivation (45). Correspondingly, MCZ possessed anti-androgenic activity in NIH3T3-AR-Luc cells treated with testosterone (46).

Taken together, the existing data demonstrate that MCZ may alter testosterone production via direct cytotoxicity to testosterone-producing Leydig cells, as well as interference with testosterone synthesis and signaling. In addition, reduction of LH in parallel with MCZ-induced decrease in testosterone production may be indicative of disruption of the negative feedback mechanism of the hypothalamus-pituitary-gonadal axis. At the same time, high-quality epidemiological data linking MCZ exposure to male infertility in humans seem to be lacking.

\section{Ovaries}

The ovaries are considered to be one of the primary targets for MCZ-induced endocrine disruption. At the organ level, MCZ exposure has been shown to cause a significant decrease in protein and glycogen content in ovaries, whereas the level of total lipids, phospholipids, and neutral lipids was increased in parallel with a reduction in ovarian size and corpus luteum number in rats (47). These changes were also associated with a significant decrease in follicle number and the number of cycles, whereas the number of atretic follicles increased substantially in response to MCZ exposure in mice (48). Similar patterns were characteristic of MCZ-induced inhibition of compensatory ovarian hypertrophy in hemicastrated female rats (49). 
MCZ-induced decrease in follicle number was shown to be associated with apoptosis that was ameliorated by vitamin $\mathrm{C}$ and $\mathrm{E}$ supplementation, implicating oxidative stress in MCZ-induced ovarian toxicity in mice (50). A combination of these vitamins was also shown to be beneficial in the improvement of oocyte maturation, fertilization and implantation rates, and embryo development in first-generation mice pups from MCZ-exposed dams (51).

MCZ induced a dose-dependent cytotoxic effect on granulosa cells, characterized by altered intracellular contacts, membrane damage, chromatin condensation, cytoplasmic vacuolization, and reduced mitochondria length in mice (52). Given the role of granulosa cells in estradiol synthesis, MCZ cytotoxicity may result in reduced estradiol synthesis. Alteration of adrenal estradiol synthesis may also contribute to female reproductive system dysfunction (53).

A significant decrease in granulosa cell viability in response to mancozeb treatment was associated with increased progesterone levels. Taken together with the observed decrease in oocyte cumulus expansion and maturation upon MCZ exposure, this suggests that increased progesterone production may inhibit ovulation in caprines (54).

It is proposed that the mechanisms underlying mancozeb-induced granulosa cell dysfunction may involve oxidative stress, mitochondrial dysfunction, impaired ATP production, as well as p53 down-regulation (55). The observed decrease in both mRNA and protein p53 expression in MCZ-exposed granulosa cells was associated with increased cell migration, thus inducing premalignant changes (56). In contrast, granulosa cells from MCZ-exposed mice were characterized by a higher apoptotic rate, which could be reversed by antioxidant resveratrol treatment (57), corroborating the previously discussed association between MCZ exposure and oxidative stress in granulosa cells.

In contrast, progesterone synthesis in bovine luteal cells was inhibited by mancozeb exposure, being indicative of MCZ-induced inhibition of P450scc (CYP11A1) and 3betaHSD (HSD3B1) enzymes (58). Correspondingly, chemical modeling analysis revealed capability of MCZ methyl group to interact with hydroxyl group of Asn315 residue in CYP11A1 (59).

As a result of endocrine dysfunction, exposure of female mice to mancozeb was shown to reduce meiotic maturation of the oocytes and its arrest in metaphase II, as well as decreased formation of oocyte pronuclei following in vitro fertilization (60). Even in oocytes reaching metaphase II, mancozeb exposure resulted in significant alterations of meiotic spindle formation, predominantly characterized by impaired microtubule length (61).

The above-mentioned changes in the ovarian function due to $\mathrm{MCZ}$ exposure were shown to be associated with impaired implantation in mice (62). Reduced trophoblastic spheroid attachment to endometrial epithelial cells in MCZ exposed animals may be at least partially mediated by down-regulation of endometrial estrogen receptor $\beta$ receptor and integrin $\beta 3$ expression, whereas ETU itself did not possess such an inhibitory effect 
(63). In addition, even in the lack of significant changes of decidualization markers in endometrial stromal cells, MCZ suppressed decidualization-induced morphological changes in stroma cells that may be associated with altered Prostaglandin E synthase transcription and protein expression (64).

In contrast to male effects, the existing epidemiological data demonstrate that $\mathrm{MCZ}$ exposure may significantly affect female fertility and adverse pregnancy outcomes, resulting in altered menstrual cycle, spontaneous abortions, miscarriage, as well as adverse developmental outcome in children (17).

\section{Adrenals}

Several studies demonstrated that the adrenals may also be considered as potential targets for mancozeb endocrine-disrupting activity. Specifically, even in the absence of cytotoxic effects in rainbow trout adrenocortical cells, MCZ exposure was shown to inhibit dibutyryl-cAMP- and ACTH-induced cortisol secretion (65). Molecular docking analysis of the interaction between $\mathrm{MCZ}$ with steroidogenic enzymes demonstrated that MCZ was characterized by the highest binding affinity to CYP11B1, a 11-betahydroxylase of the adrenal cortex involved in the biosynthesis of cortisol and corticosterone (66). Moreover, in an angiotensin-II-responsive steroid-producing adrenocortical cell line H295R, mancozeb exposure was shown to be associated with estradiol levels (67).

\section{Adipose tissue}

In the last decades, adipose tissue has been considered as a novel endocrine organ secreting a wide spectrum of molecules with systemic effects (68). Certain studies demonstrated the potential impact of MCZ exposure on PPAR $\gamma$, the key adipogenesis regulator (69). Specifically, in in silico molecular docking analysis, MCZ was shown to bind PPAR $\gamma$ through interaction between thiomethyl and amino acid residues of the fungicide with Arg288, Ser289, His323, and Tyr327 residues in PPAR $\gamma$ molecule (70).

At the same time, in an in vitro study mancozeb was found to be cytotoxic to adipocytes without any significant influence on mPPAR $\gamma$ activation (71). In agreement with this, MCZ exposure was shown to reduce adipogenesis in a culture of adipocytes, although it increased model adipose tissue vascularization in non-toxic concentrations (72).

\section{Neurotoxicity as a potential contributor to mez endocrine disrupting activity}

The existing studies of endocrine disrupting activity of MCZ directly or, more frequently, indirectly implicate the role of altered hypothalamus-hypophysis-gland (thyroid, adrenal, or gonad) in mediating the observed adverse effects. Despite the lack of clear evidence, it has been proposed that toxic effects of MCZ and ETU exposure on neuronal structures may result in endocrine dysfunction due to the role of hypothalamus 
as a central controller of endocrine system functioning (73). This hypothesis was indirectly supported by the role of neurotoxin-induced hypothalamic damage in the dysregulation of hypothalamic-pituitary axis (74). In this regard, MCZ neurotoxicity will be briefly reviewed herein.

Both $\mathrm{MCZ}$ and maneb exposure were shown to possess neurotoxic effects in rat dopamine and GABA mesencephalic populations, inducing mitochondrial dysfunction characterized by the inhibition of respiratory chain complex I activity. It is noteworthy that neurotoxic effects were mediated by both organic moiety and Mn2+ (75). Correspondingly, DA and GABAergic neurons were characterized by degeneration in MCZ-exposed C. elegans (76). These findings corroborate earlier indications of Mn2+ toxicity (77) with a special focus on dopaminergic and GABAergic neurons (78). It has been also demonstrated that microglia activation may significantly contribute to MCZinduced $\mathrm{H}_{2} \mathrm{O}_{2}$ generation in mesencephalic dopamine and GABA cell populations, which was also found to be $\mathrm{Mn} 2+$, but not $\mathrm{Zn} 2+$-dependent (79). Moreover, increased Mn2+ brain accumulation following MCZ exposure was associated with reactive oxygen species (ROS) overproduction and a compensatory activation of Nrf2/ARE signaling in brain (80). Finally, MCZ exposure was shown to increase APP and A $\beta 42$ protein expression in PC12 cells, as well as activate the double-stranded RNA dependent protein kinase that is known to promote neuronal apoptosis (81). In addition, proapoptotic signaling was characterized by modulation of Bcl-2, Bax, Caspase 3, and caspase 9 mRNA expression in adult zebrafish brain (82).

Several studies have also demonstrated the adverse effects of MCZ exposure on neurotransmitter metabolism. Specifically, the levels of excitatory transmitters, glutamate and aspartate, were reduced in the early postnatal period, whereas at the age of one month cerebellar cortex was characterized by the elevation of glutamate and reduction of aspartate (83). An increase in excitatory neurotransmitter release in response to MCZ exposure was also associated with mitochondrial and synaptic dysfunction, as well as neuroinflammation (84). These findings generally corroborate the observation of MCZinduced inhibition of ATP-dependent vesicular uptake of glutamate (85).

MCZ-induced neurodegeneration at diencephalic sites in Ornate wrasses was also associated with increased orexin mRNA and protein expression, being associated with reduced food intake $(86)$.

It is also notable that behavioral deficits in MCZ-exposed C. elegans may precede profound structural damage in response to $\mathrm{MCZ}$ exposure (87), indicating early neuronal effects in the course of MCZ toxicity.

Consistently with the laboratory data, human biomonitoring studies demonstrated that MCZ exposure was shown to affect neurodevelopment in children. Specifically, MCZ exposure as assessed by increased ETU concentrations was shown to be associated with poorer verbal learning ability (88), impaired social-emotional development (89), and semantic memory (90). Although MCZ neurotoxicity may underlie these effects, it is also 
proposed that altered sex hormone dysregulation or thyroid dysfunction may also affect the developing brain.

\section{Conclusions}

The existing data demonstrate that MCZ possesses significant endocrine-disrupting properties in the thyroid and gonads, inducing its effects through toxic damage to hormone-producing cells, inhibition of the enzymes involved in hormone biosynthesis, modulation of hormonal receptors, as well as dysregulation of hypothalamus-pituitarygland axis. At the same time, an increasing body of data demonstrates that other endocrine tissues, including adipose tissue and adrenals, may be the targets of MCZ toxicity (Figure $4)$.

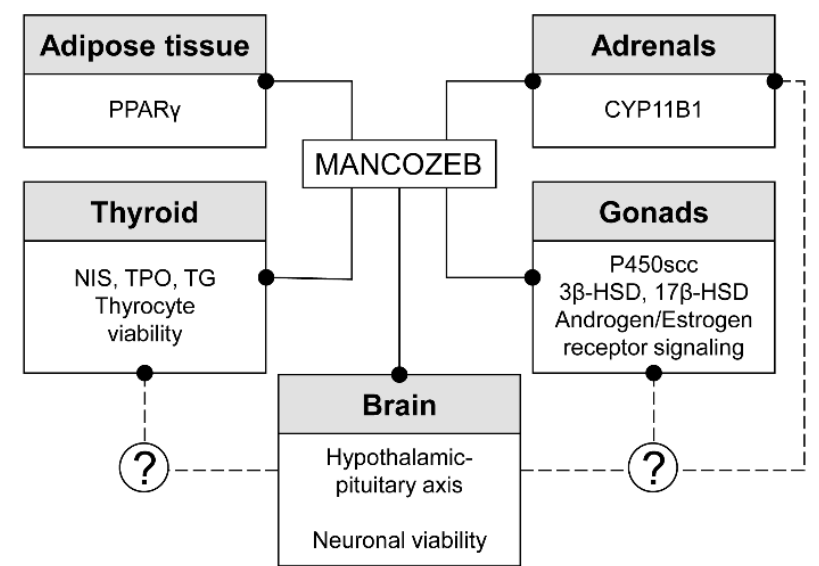

Figure 4. Targets of mancozeb endocrine-disrupting activity and the potential role of neurotoxicity in endocrine dysfunction through alteration of hypothalamicpituitary axis.

Figure 4. Ciljna tkiva i organi mankozeba kao endokrinog ometača i moguća uloga neurotoksičnosti u endokrinoj disfunkciji putem izmene ose hipotalamushipofiza.

In addition, due to the role of hypothalamic structures in central control of endocrine system functioning, it has been proposed that MCZ neurotoxicity may at least partially contribute to endocrine disrupting effects of the fungicide. However, further studies are required to unravel the mechanisms of $\mathrm{MCZ}$ endocrine-disrupting activity and overall toxicity.

\section{Conflict of interest}

The authors declare no conflict of interest. 


\section{Financial support}

MA was supported in parts by a grant from the National Institute of Environmental Health Science (NIEHS) R01 ES10563. JBTR is a recipient of CNPq fellowship and CAPES-PROEX-EPIDEMIAS09 grant. The study was performed with the support of the Russian Ministry of Science and Higher Education, Project № 0856-2020-0008.

\section{Ethics statement: N.A}

\section{References}

1. Gullino ML, Tinivella F, Garibaldi A, Kemmitt GM, Bacci L, Sheppard B. Mancozeb: Past, Present, and Future. Plant Dis. 2010 Sep;94(9):1076-1087.

2. European Food Safety Authority (EFSA), Abdourahime H, Anastassiadou M, Arena M, Auteri D, Barmaz S, et al. Peer review of the pesticide risk assessment of the active substance mancozeb. EFSA J. 2020;18(12):e05755.

3. $\mathrm{Xu}$ S. Environmental fate of mancozeb [Internet]. [cited 2021 Nov 28]. Available from: https://pdfs.semanticscholar.org/26d4/81cec3f47370ff32a1b3c26e4ab3b8211851.pdf.

4. Hanumantharaju TH, Awasthi MD. Persistence and degradation of metalaxyl, mancozeb fungicides and its metabolite ethylenethiourea in soils. J Environ Sci Eng. 2004;46(4):312-21.

5. Domínguez-Rodríguez V, Obrador-Olán JJ, Adams RH, Zavala-Cruz J, Vaquera-Huerta H, Guerrero-Peña A, et al. Occupational and environmental risks from mancozeb in aviation facilities in the banana producing area of Teapa, Tabasco, Mexico. Trop J Pharm Res. 2015;14(9):1703-1712.

6. López-Fernández O, Rial-Otero R, Simal-Gándara J. Factors governing the removal of mancozeb residues from lettuces with washing solutions. Food Control. 2013;34(2):530-538.

7. Mandic-Rajcevic S, Rubino FM, Ariano E, Cottica D, Neri S, Colosio C. Environmental and biological monitoring for the identification of main exposure determinants in vineyard mancozeb applicators. J Expo Sci Environ Epidemiol. 2018;28(3):289-296.

8. Dall'Agnol JC, Ferri Pezzini M, Suarez Uribe N, Joveleviths D. Systemic effects of the pesticide mancozeb - A literature review. Eur Rev Med Pharmacol Sci. 2021;25(11):4113-4120.

9. Atreya K, Sitaula BK. Mancozeb: growing risk for agricultural communities?. Himalayan J H Sci. 2010; 6(8): 9-10.

10. van Wendel de Joode B, Mora AM, Córdoba L, Cano JC, Quesada R, Faniband M, et al. Aerial application of mancozeb and urinary ethylene thiourea (ETU) concentrations among pregnant women in Costa Rica: the Infants' Environmental Health Study (ISA). Environ Health Perspect. 2014 Dec;122(12):1321-8.

11. Easton A, Guven K, de Pomerai DI. Toxicity of the dithiocarbamate fungicide mancozeb to the nontarget soil nematode, Caenorhabditis elegans. J Biochem Mol Toxicol. 2001;15(1):15-25. 
12. Corsini E, Birindelli S, Fustinoni S, De Paschale G, Mammone T, Visentin S, et al. Immunomodulatory effects of the fungicide Mancozeb in agricultural workers. Toxicol Appl Pharmacol. 2005 Oct 15;208(2):178-85.

13. Yahia D, El-Amir YO, Rushdi M. Mancozeb fungicide-induced genotoxic effects, metabolic alterations, and histological changes in the colon and liver of Sprague Dawley rats. Toxicol Ind Health. 2019 Apr;35(4):265-276.

14. Pirozzi AVA, Stellavato A, La Gatta A, Lamberti M, Schiraldi C. Mancozeb, a fungicide routinely used in agriculture, worsens nonalcoholic fatty liver disease in the human HepG2 cell model. Toxicol Lett. 2016; 249: 1-4.

15. Zago AM, Faria NMX, Fávero JL, Meucci RD, Woskie S, Fassa AG. Pesticide exposure and risk of cardiovascular disease: A systematic review. Glob Public Health. 2020 Aug 20:1-23.

16. Belpoggi F, Soffritti M, Guarino M, Lambertini L, Cevolani D, Maltoni C. Results of long-term experimental studies on the carcinogenicity of ethylene-bis-dithiocarbamate (Mancozeb) in rats. Ann N Y Acad Sci. 2002 Dec;982:123-36.

17. Runkle J, Flocks J, Economos J, Dunlop AL. A systematic review of Mancozeb as a reproductive and developmental hazard. Environ Int. 2017 Feb;99:29-42.

18. Bianchi S, Nottola SA, Torge D, Palmerini MG, Necozione S, Macchiarelli G. Association between Female Reproductive Health and Mancozeb: Systematic Review of Experimental Models. Int J Environ Res Public Health. 2020 Apr 9;17(7):2580.

19. Medda E, Santini F, De Angelis S, Franzellin F, Fiumalbi C, Perico A, et al. Iodine nutritional status and thyroid effects of exposure to ethylenebisdithiocarbamates. Environ Res. 2017 Apr;154:152-159.

20. Kwon D, Chung HK, Shin WS, Park YS, Kwon SC, Song JS, et al. Toxicological evaluation of dithiocarbamate fungicide mancozeb on the endocrine functions in male rats. Mol Cell Toxicol 2018;14(1):105-112.

21. European Food Safety Authority (EFSA), Abdourahime H, Anastassiadou M, Arena M, Auteri D, Barmaz S, et al. Peer review of the pesticide risk assessment of the active substance mancozeb. EFSA J. 2020 Dec 16;18(12):e05755.

22. Santos R, Piccoli C, Cremonese C, Freire C. Thyroid and reproductive hormones in relation to pesticide use in an agricultural population in Southern Brazil. Environ Res. 2019 Jun;173:221-231.

23. Shrestha S, Parks CG, Goldner WS, Kamel F, Umbach DM, Ward MH, et al. Incident thyroid disease in female spouses of private pesticide applicators. Environ Int. 2018 Sep;118:282-292.

24. Nordby KC, Andersen A, Irgens LM, Kristensen P. Indicators of mancozeb exposure in relation to thyroid cancer and neural tube defects in farmers' families. Scand J Work Environ Health. 2005 Apr;31(2):89-96.

25. Pandey SP, Mohanty B. The neonicotinoid pesticide imidacloprid and the dithiocarbamate fungicide mancozeb disrupt the pituitary-thyroid axis of a wildlife bird. Chemosphere. 2015 Mar;122:227-234.

26. Axelstad M, Boberg J, Nellemann C, Kiersgaard M, Jacobsen PR, Christiansen S, et al. Exposure to the widely used fungicide mancozeb causes thyroid hormone disruption in rat dams but no behavioral effects in the offspring. Toxicol Sci. 2011 Apr;120(2):439-46.

27. Jacobsen PR, Axelstad M, Boberg J, Isling LK, Christiansen S, Mandrup KR, et al. Persistent developmental toxicity in rat offspring after low dose exposure to a mixture of endocrine disrupting pesticides. Reprod Toxicol. 2012 Sep;34(2):237-50. 
28. Ksheerasagar RL, Kaliwal BB. Temporal effects of mancozeb on testes, accessory reproductive organs and biochemical constituents in albino mice. Environ Toxicol Pharmacol. 2003 Dec;15(1):9-17.

29. Damayanthi D. Insilico studies on the disruption of the pituitary-thyroid axis by the dithiocarbamate fungicide mancozeb. World J Pharm Res. 2015;4(3):1569-1578.

30. Bhaskar R, Mohanty B. Pesticides in mixture disrupt metabolic regulation: in silico and in vivo analysis of cumulative toxicity of mancozeb and imidacloprid on body weight of mice. Gen Comp Endocrinol. 2014 Sep 1;205:226-34.

31. Hallinger DR, Murr AS, Buckalew AR, Simmons SO, Stoker TE, Laws SC. Development of a screening approach to detect thyroid disrupting chemicals that inhibit the human sodium iodide symporter (NIS). Toxicol In Vitro. 2017 Apr;40:66-78.

32. Thienpont B, Tingaud-Sequeira A, Prats E, Barata C, Babin PJ, Raldúa D. Zebrafish eleutheroembryos provide a suitable vertebrate model for screening chemicals that impair thyroid hormone synthesis. Environ Sci Technol. 2011 Sep 1;45(17):7525-32.

33. Price RJ, Burch R, Chatham LR, Higgins LG, Currie RA, Lake BG. An assay for screening xenobiotics for inhibition of rat thyroid gland peroxidase activity. Xenobiotica. 2020 Mar;50(3):318-322.

34. Hernández AF, Bennekou SH, Hart A, Mohimont L, Wolterink G. Mechanisms underlying disruptive effects of pesticides on the thyroid function. Curr Opin Toxicol 2020; 19: 34-41.

35. Porreca I, D'Angelo F, De Franceschi L, Mattè A, Ceccarelli M, Iolascon A, et al. Pesticide toxicogenomics across scales: in vitro transcriptome predicts mechanisms and outcomes of exposure in vivo. Sci Rep. 2016 Dec 1;6:38131.

36. La Vecchia C, Turati F, Negri E. Exposure to antithyroid drugs and ethylenethiourea and risk of thyroid cancer: a systematic review of the epidemiologic evidence. Eur J Canc Prev. 2021;31(1):64-72.

37. Panganiban L, Cortes-Maramba N, Dioquino C, Suplido ML, Ho H, Francisco-Rivera A, et al. Correlation between blood ethylenethiourea and thyroid gland disorders among banana plantation workers in the Philippines. Environ Health Perspect. 2004 Jan;112(1):42-5.

38. Joshi SC, Gulati N, Gajraj A. Evaluation of toxic impacts of mancozeb on testis in rats. Asian J Exp Biol Sci. 2005;19(1):73-83.

39. Forouzandeh H, Ahmadi I, Akbari H. The Protective Effect of Chicoric Acid on the Mancozebinduced Male Reproductive Damage in Mice. Arch Med Lab Sci. 2021;7:1-10.

40. Saddein E, Haghpanah T, Nematollahi-Mahani SN, Seyedi F, Ezzatabadipour M. Preventative Effects of Vitamin E on Testicular Damage and Sperm Parameters in the First-Generation Mice Pups due to Pre- and Postnatal Mancozeb Exposure. J Toxicol. 2019 Aug 1;2019:4763684.

41. Manfo FP, Chao WF, Moundipa PF, Pugeat M, Wang PS. Effects of maneb on testosterone release in male rats. Drug Chem Toxicol. 2011 Apr;34(2):120-8.

42. Girish BP, Reddy PS. Forskolin ameliorates mancozeb-induced testicular and epididymal toxicity in Wistar rats by reducing oxidative toxicity and by stimulating steroidogenesis. J Biochem Mol Toxicol. 2018 Feb;32(2).

43. Elsharkawy EE, El-Nasser MA, Bakheet AA. Mancozeb impaired male fertility in rabbits with trials of glutathione detoxification. Regul Toxicol Pharmacol. 2019 Jul;105:86-98.

44. Mohammadi-Sardoo M, Mandegary A, Nabiuni M, Nematollahi-Mahani SN, Amirheidari B. Mancozeb induces testicular dysfunction through oxidative stress and apoptosis: Protective role of N-acetylcysteine antioxidant. Toxicol Ind Health. 2018 Nov;34(11):798-811. 
45. Kjeldsen LS, Ghisari M, Bonefeld-Jørgensen EC. Currently used pesticides and their mixtures affect the function of sex hormone receptors and aromatase enzyme activity. Toxicol Appl Pharmacol. 2013 Oct 15;272(2):453-64.

46. Viswanath G, Chatterjee S, Dabral S, Nanguneri SR, Divya G, Roy P. Anti-androgenic endocrine disrupting activities of chlorpyrifos and piperophos. J Steroid Biochem Mol Biol. 2010 May;120(1):22-9.

47. Baligar PN, Kaliwal BB. Induction of gonadal toxicity to female rats after chronic exposure to mancozeb. Ind Health. 2001 Jul;39(3):235-43.

48. Kaliwal BB, Parimala MD. Dose-Dependent Estrous Cycle, Ovarian Follicles and Biochemical Contents Reversal in Albino Mice after Exposure to Mancozeb. Casp J Environ Sci. 2006;4(2):118-131.

49. Mahadevaswami MP, Jadaramkunti UC, Hiremath MB, Kaliwal BB. Effect of mancozeb on ovarian compensatory hypertrophy and biochemical constituents in hemicastrated albino rat. Reprod Toxicol. 2000 Mar-Apr;14(2):127-34.

50. Mahdi H, Tahereh H, Esmaiel S, Massood E. Vitamins E and C prevent apoptosis of testicular and ovarian tissues following mancozeb exposure in the first-generation mouse pups. Toxicol Ind Health. 2019 Feb;35(2):136-144.

51. Esmaiel S, Tahereh H, Noreddin NS, Massood E. Mancozeb exposure during development and lactation periods results in decreased oocyte maturation, fertilization rates, and implantation in the first-generation mice pups: Protective effect of vitamins E and C. Toxicol Ind Health. 2019 NovDec;35(11-12):714-725.

52. Palmerini MG, Belli M, Nottola SA, Miglietta S, Bianchi S, Bernardi S, et al. Mancozeb impairs the ultrastructure of mouse granulosa cells in a dose-dependent manner. J Reprod Dev. 2018 Feb 27;64(1):75-82.

53. Hadrup N, Taxvig C, Pedersen M, Nellemann C, Hass U, Vinggaard AM. Concentration addition, independent action and generalized concentration addition models for mixture effect prediction of sex hormone synthesis in vitro. PLoS One. 2013 Aug 22;8(8):e70490.

54. Dinisri I, Kodikara S, Prasadani M, Pathirana I, Rathnayake C, Alexander B, et al. Impairment of caprine oocyte maturation in vitro and alteration of granulosa cells functions by widely used fungicide mancozeb. Trop Anim Health Prod. 2021 Jul 21;53(3):406.

55. Iorio R, Castellucci A, Rossi G, Cinque B, Cifone MG, Macchiarelli G, et al. Mancozeb affects mitochondrial activity, redox status and ATP production in mouse granulosa cells. Toxicol In Vitro. 2015 Dec 25;30(1 Pt B):438-45.

56. Paro R, Tiboni GM, Buccione R, Rossi G, Cellini V, Canipari R, et al. The fungicide mancozeb induces toxic effects on mammalian granulosa cells. Toxicol Appl Pharmacol. 2012 Apr 15;260(2):155-61.

57. Liu Y, Wang YL, He SW, Chen MH, Zhang Z, Fu XP, et al. Protective effects of resveratrol against mancozeb induced apoptosis damage in mouse oocytes. Oncotarget. 2017 Jan 24;8(4):6233-6245.

58. Atmaca N, Arikan S, Essiz D, Kalender H, Simsek O, Bilmen FS, et al. Effects of mancozeb, metalaxyl and tebuconazole on steroid production by bovine luteal cells in vitro. Environ Toxicol Pharmacol. 2018 Apr;59:114-118.

59. Bhaskar R, Mishra AK, Mohanty B. Effects of mancozeb and imidacloprid pesticides on activities of steroid biosynthetic enzymes cytochromes P450. J Kalash Sci. 2014;2:1-6. 
60. Rossi G, Buccione R, Baldassarre M, Macchiarelli G, Palmerini MG, Cecconi S. Mancozeb exposure in vivo impairs mouse oocyte fertilizability. Reprod Toxicol. 2006 Feb;21(2):216-9.

61. Rossi G, Palmerini MG, Macchiarelli G, Buccione R, Cecconi S. Mancozeb adversely affects meiotic spindle organization and fertilization in mouse oocytes. Reprod Toxicol. 2006b Jul;22(1):51-5.

62. Bindali BB, Kaliwal BB. Anti-implantation effect of a carbamate fungicide mancozeb in albino mice. Ind. Health. 2002;40(2):191-197.

63. Wang Z, Kottawatta KSA, Kodithuwakku SP, Fernando TS, Lee YL, Ng EHY, et al. The fungicide Mancozeb reduces spheroid attachment onto endometrial epithelial cells through downregulation of estrogen receptor $\beta$ and integrin $\beta 3$ in Ishikawa cells. Ecotoxicol Environ Saf. 2021 Jan 15;208:111606.

64. Akthar I, Wang Z, Wijayagunawardane MPB, Ratnayake CJ, Siriweera EH, Lee KF, et al. In vitro and in vivo impairment of embryo implantation by commonly used fungicide Mancozeb. Biochem Biophys Res Commun. 2020 Jun 18;527(1):42-48.

65. Bisson M, Hontela A. Cytotoxic and endocrine-disrupting potential of atrazine, diazinon, endosulfan, and mancozeb in adrenocortical steroidogenic cells of rainbow trout exposed in vitro. Toxicol Appl Pharmacol. 2002 Apr 15;180(2):110-7.

66. Bhaskar R, Mishra AK, Mohanty B. Effects of mancozeb and imidacloprid pesticides on activities of steroid biosynthetic enzymes cytochromes P450. J Kalash Sci 2014; 2: 1-6.

67. Hadrup N, Taxvig C, Pedersen M, Nellemann C, Hass U, Vinggaard AM. Concentration addition, independent action and generalized concentration addition models for mixture effect prediction of sex hormone synthesis in vitro. PLoS One. 2013 Aug 22;8(8):e70490.

68. Galic S, Oakhill JS, Steinberg GR. Adipose tissue as an endocrine organ. Mol Cell Endocrinol. 2010 Mar 25;316(2):129-39.

69. Lefterova MI, Haakonsson AK, Lazar MA, Mandrup S. PPAR $\gamma$ and the global map of adipogenesis and beyond. Trends Endocrinol Metab. 2014 Jun;25(6):293-302.

70. Bhaskar R, Mohanty B. Pesticides in mixture disrupt metabolic regulation: in silico and in vivo analysis of cumulative toxicity of mancozeb and imidacloprid on body weight of mice. Gen Comp Endocrinol. 2014 Sep 1;205:226-34.

71. Taxvig C, Dreisig K, Boberg J, Nellemann C, Schelde AB, Pedersen D, et al. Differential effects of environmental chemicals and food contaminants on adipogenesis, biomarker release and PPAR $\gamma$ activation. Mol Cell Endocrinol. 2012 Sep 25;361(1-2):106-15.

72. Huttala O, Sarkanen JR, Heinonen T, Ylikomi T. Presence of vasculature results in faster insulin response in adipocytes in vascularized adipose tissue model. ALTEX. 2019;36(3):419-434.

73. Clarke IJ. Hypothalamus as an endocrine organ. Compr Physiol. 2015 Jan;5(1):217-53.

74. Spinedi E, Johnston C, Negro-Vilar A. Increased responsiveness of the hypothalamic-pituitary axis after neurotoxin-induced hypothalamic denervation. Endocrinology. 1984 Jul;115(1):267-72.

75. Domico LM, Zeevalk GD, Bernard LP, Cooper KR. Acute neurotoxic effects of mancozeb and maneb in mesencephalic neuronal cultures are associated with mitochondrial dysfunction. Neurotoxicology. 2006 Sep;27(5):816-25. 
76. Negga R, Stuart JA, Machen ML, Salva J, Lizek AJ, Richardson SJ, et al. Exposure to glyphosateand/or $\mathrm{Mn} / \mathrm{Zn}$-ethylene-bis-dithiocarbamate-containing pesticides leads to degeneration of $\gamma$ aminobutyric acid and dopamine neurons in Caenorhabditis elegans. Neurotox Res. 2012 Apr;21(3):281-90.

77. Caito S, Aschner M. Neurotoxicity of metals. Handb Clin Neurol. 2015;131:169-89.

78. Stanwood GD, Leitch DB, Savchenko V, Wu J, Fitsanakis VA, Anderson DJ, et al. Manganese exposure is cytotoxic and alters dopaminergic and GABAergic neurons within the basal ganglia. J Neurochem. 2009 Jul;110(1):378-89.

79. Domico LM, Cooper KR, Bernard LP, Zeevalk GD. Reactive oxygen species generation by the ethylene-bis-dithiocarbamate (EBDC) fungicide mancozeb and its contribution to neuronal toxicity in mesencephalic cells. Neurotoxicology. 2007 Nov;28(6):1079-91.

80. Costa-Silva DG, Lopes AR, Martins IK, Leandro LP, Nunes MEM, de Carvalho NR, et al. Mancozeb exposure results in manganese accumulation and Nrf2-related antioxidant responses in the brain of common carp Cyprinus carpio. Environ Sci Pollut Res Int. 2018 Jun;25(16):15529-15540.

81. Cheng SY, Lopez Y, Montes J. Maneb and Mancozeb Increase Amyloid $\beta$ Precursor Protein Expression and Activate PKR. J Cell Sci Apo. 2017;1:110.

82. Kuppuswamy JM, Seetharaman B. Mancozeb exposure at sublethal concentration alters the transcription of the genes related to apoptosis in the adult zebrafish (Danio rerio) brain. Res J Pharm Technol. 2020;13(10):4801-4804.

83. Miranda-Contreras L, Dávila-Ovalles R, Benítez-Díaz P, Peña-Contreras Z, Palacios-Prü E. Effects of prenatal paraquat and mancozeb exposure on amino acid synaptic transmission in developing mouse cerebellar cortex. Brain Res Dev Brain Res. 2005 Nov 7;160(1):19-27.

84. Peña-Contreras, Z, Miranda-Contreras, L, Morales-Ovalles, Y, Colmenares-Sulbarán, M, DávilaVera, D, Balza-Quintero, A, et al. Atrazine and mancozeb induce excitotoxicity and cytotoxicity in primary cultures of mouse cerebellar cortex. Toxicological and environmental chemistry. 2016;98:959-976.

85. Vaccari A, Saba P, Mocci I, Ruiu S. Dithiocarbamate pesticides affect glutamate transport in brain synaptic vesicles. J Pharmacol Exp Ther. 1999 Jan;288(1):1-5.

86. Zizza M, Di Lorenzo M, Laforgia V, Furia E, Sindona G, Canonaco M, et al. Orexin receptor expression is increased during mancozeb-induced feeding impairments and neurodegenerative events in a marine fish. Neurotoxicology. 2018 Jul;67:46-53.

87. Harrison Brody A, Chou E, Gray JM, Pokyrwka NJ, Raley-Susman KM. Mancozeb-induced behavioral deficits precede structural neural degeneration. Neurotoxicology. 2013 Jan;34:74-81.

88. van Wendel de Joode B, Mora AM, Lindh CH, Hernández-Bonilla D, Córdoba L, Wesseling C, et al. Pesticide exposure and neurodevelopment in children aged 6-9 years from Talamanca, Costa Rica. Cortex. 2016 Dec;85:137-150.

89. Mora AM, Córdoba L, Cano JC, Hernandez-Bonilla D, Pardo L, Schnaas L, et al. Prenatal Mancozeb Exposure, Excess Manganese, and Neurodevelopment at 1 Year of Age in the Infants' Environmental Health (ISA) Study. Environ Health Perspect. 2018;126(5):057007.

90. Fuhrimann S, Farnham A, Staudacher P, Atuhaire A, Manfioletti T, Niwagaba CB, et al. Exposure to multiple pesticides and neurobehavioral outcomes among smallholder farmers in Uganda. Environ Int. $2021 \mathrm{Jul} ; 152: 106477$. 


\title{
Delovanje mankozeba kao endokrinog ometača
}

\author{
Anatoly Skalny 1,2,3, Michael Aschner ${ }^{1,4}$, Monica Paoliello ${ }^{4}$, \\ Abel Santamaria ${ }^{5}$, Natalia Nikitina ${ }^{1}$, Vladimir Rejniuk ${ }^{6}$, \\ Yueming Jiang ${ }^{7}$, João Rocha ${ }^{8}$, Alexey Tinkov ${ }^{2,3,9}$ \\ ${ }^{1}$ IM Sechenov First Moscow State Medical University, Moscow 119146, Russia \\ ${ }^{2}$ Peoples' Friendship University of Russia (RUDN University), Moscow 117198, Russia \\ ${ }^{3}$ Institute of Bioelementology, Orenburg State University, Orenburg 460018, Russia \\ ${ }^{4}$ Department of Molecular Pharmacology, Albert Einstein College of Medicine, Bronx, \\ NY 10461, USA \\ ${ }^{5}$ Laboratorio de Aminoácidos Excitadores/Laboratorio de Neurofarmacología Molecular y \\ Nanotecnología, Instituto Nacional de Neurología y Neurocirugía, Mexico City 14269, Mexico \\ ${ }^{6}$ Golikov Research Center of Toxicology, Saint Petersburg 192019, Russia \\ ${ }^{7}$ Department of Toxicology, School of Public Health, Guangxi Medical University, \\ Nanning 530021, China \\ ${ }^{8}$ Departamento de Bioquímica e Biologia Molecular, CCNE, Universidade Federal de Santa \\ Maria, Santa Maria, RS, Brazil \\ ${ }^{9}$ Yaroslavl State University, Yaroslavl 150000, Russia
}

* Autor za korespondenciju: Alexey Tinkov, e-mail: tinkov.a.a@gmail.com

\section{Kratak sadržaj}

Ovo istraživanje je imalo za cilj da pruži pregled postojećih podataka o mehanizmima uključenim u delovanje mankozeba (MCZ) kao endokrinog ometača u ciljnim organima, u koja se ubrajaju štitna i polne žlezde, kao i u ostalim endokrinim tkivima na koja potencijalno može uticati MCZ. Pokazalo se da izloženost mankozebu remeti rad štitne žlezde tako što ometa sintezu tiroidnih hormona inhibirajući aktivnost natrijum-jodid simportera (NIS) i tiroidne perioksidaze (TPO), kao i ekspresiju tiroglobulina. Neposredno tirotoksično dejstvo takođe može doprineti razvoju tiroidne patologije pri izlaganju mankozebu. Delovanje mankozeba na polne žlezde uključuje inhibiciju sinteze polnih steroida usled inhibicije P450scc (CYP11A1), kao i 33-HSD i $17 \beta$-HSD. Uporedo sa promenama u sintezi hormona, pokazalo se da MCZ snižava slanje signala androgenih i estrogenih receptora. Ovi efekti koji se odnose na polne žlezde zajedno dovode do pojave reproduktivne disfunkcije kako kod muškaraca, tako i kod žena. Pored jasno utvrđenih ciljnih organa na koja MCZ deluje kao endokrini ometač, mogu biti pogođena i druga endokrina tkiva. Konkretno, pokazalo se da ovaj fungicid utiče na sintezu kortizola, moguće posredstvom modulacije aktivnosti CYP11B1. Pored toga, utvrđeno je da izloženost mankozebu remeti signale $\operatorname{PPAR} \gamma$, koji su ključni regulator adipogeneze. Postojeći podaci takođe ukazuju na to da do posledica izloženosti mankozebu može doći posredstvom modulacije ose hipotalamus-hipofizaciljni organ. Navodi se da je moguće da neurotoksičnost mankozeba makar delimično utiče na centralne mehanizme rada endokrinog sistema. Ipak, neophodna su dalja istraživanja kako bi se razjasnili ne samo mehanizmi delovanja mankozeba kao endokrinog ometača već i njegova toksičnost uopšte.

Ključne reči: mankozeb, štitna žlezda, testisi, jajnici, nadbubrežna žlezda, adipozno tkivo 